\title{
初期エネルギー分布を変えた場合のPDPセル内の 電子スオームの挙動
}

\author{
正員福 山達 也 (千葉工業大学) \\ 正員伊 藤 晴 雄 (千葉工業大学)
}

Electron Swarm Behavior in a PDP Cell Dependent

on the Initial Energy Distribution of Electrons

Tatsuya Fukuyama, Member, Haruo Itoh, Member (Chiba Institute of Technology)

\begin{abstract}
This paper describes the influence of initial energy distribution of the electron emitted from the cathode on the behavior of the electron swarm in a PDP cell. Spatial and temporal distributions of the electron transport coefficients are obtained with two types of the initial energy distribution of electrons at the cathode. The results for the electron transport coefficients in the equilibrium region almost agree, but large differences are found in the nonequilibrium region, particularly near the cathode. If the initial energy of emitted electron from the cathode is large, the transmitted electron through gas is decreased due to the increase of the back scattering and on the contrast the multiplication factor of the collisional ionization is increased.
\end{abstract}

キーワード : PDP, 電子スオーム, 電子エネルギー分布, 電子輸送保数, モンテカルロシミュンーション

\section{1. まえがき}

著者らはプラズマディスプレイパネル (PDP) セル中の 空間電荷に支配された電界下に括けるモンテカルロシミュ レーション (MCS) を行ない, セル中の電子スオームの挙 動を調へてをた ${ }^{(1)}$ 。そこでは電極間に周期的な電圧を印加 している中から，4つの時刻における電界分布の下で MCS を行い,このような計算を行う㻮に用いられる LFA (local field approximation) の妥当性について検討した。その結 果, 特に電界の空間変化が大きい力から小さい方に変化す る埸合には，LFA は成立していないと判断できる結果を 得たことを報告した (2)。そこでの計算は，陰極から放出さ れる電子の初期エネルギ一分布は, 全て $0 \sim 0.1 \mathrm{eV}$ の間 で等確率に与えて計算したが，実際には電子衝突により He と Xe の淮安定仂起粒子やそれらの正イオン $\mathrm{He}^{+}, \mathrm{Xe}^{+}$が 生成され，これらが陰極に入射して 2 次電子放出作用を起

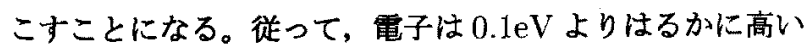
エネルギーで陰極より放出されることが十分に予想される。

本論文はこのような現象を取り入れた計算をするために, $\mathrm{He}^{+}$や $\mathrm{Xe}^{+}$がニッケル $(\mathrm{Ni})$ 陰極に入射したときに放出さ れるであろう二次電子の放出エネルギー分布を新たに与え て、これを初期電子のエネルギー分布として用いることに した。この分布は Hagstrum ${ }^{(3)}$ が実跧により確かめた $\mathrm{He}^{+}$ や Xe $\mathrm{e}^{+}$をタングステン（以下 W) 電極に入射したときに
放出される 2 次電子のエネルギー分布を参考にし，このよ うな電子の初期エネルギー分布の違いが PDP セル内の電 子スオームにどのような影隌を与えるか検討した。今回は， とりあえず電界分布は一様な場合について計算した中から 興味深い結果について報告する。

\section{MCS の計型}

〈2・1〉 MCS の旪第方法 MCS は層状発光の研究 (4)(5)に用いたコードと基本的に同じである。データ収集は 時間規準のPT (Pulsed Townsend), ならびに位置規淮の SST (Steady State Townsend) の両サンプリング法を用 いて，電子スオームの挙動を空間的，時間的に観測した。ガ スは $\mathrm{He} / \mathrm{Xe}$ 混合がス $(10 \% \mathrm{Xe})$ である。He, Xe の電子 衝突断面積は林 (6) がまとめたセットを用いた。電梅間距離 は $0.02 \mathrm{~cm}$, ガス圧力は300Torr, 電圧は PDPセル中で放 電が開始した直後の $170(\mathrm{~V})$ において比較することにした。

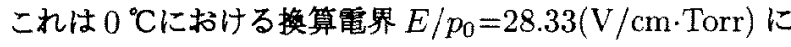
あたり、この一㴍電界の下で計算した。SST サンプリング 法を用いた計算では初期電子を陰極より $10^{4}$ 個放出し, 陽 極または陰極に達するまで計算した。PT サンプリング法 を用いた計算では，初期電子を陰極より $1 \times 10^{6}$ 個放出し， 電子の追跡時間を $20,200 \mathrm{ps} の 2$ 通りについて行なった。

〈2・2〉正子の初期エネルギー分布 図 1 に今回用い た電子の初期エネルギー分布を示す。左侧の目盛りは $\mathrm{He}^{+}$ 
により放出された電子のエネルギー分布 $F(\epsilon)_{H e}$ であり, 右 側のそれは $\mathrm{Xe}^{+}$により放出された電子のエネルギー分布 $F(\epsilon)_{X e}$ を表している。2 つの分布はそれぞれ規格化して表 示してある。

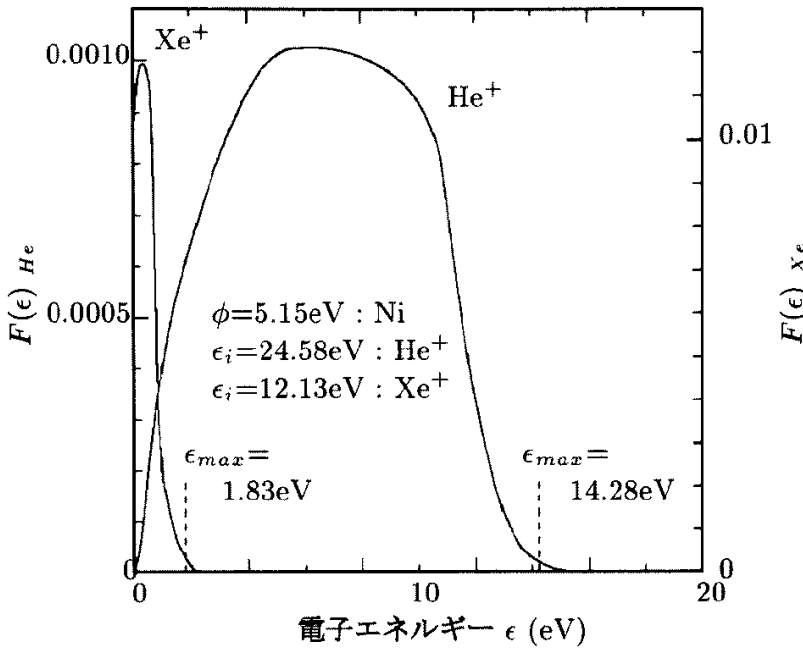

図 $1 \mathrm{Xe}^{+}$と $\mathrm{He}^{+}$により放出される電子の初期 エネルキー分布 $\mathrm{F}(\epsilon)$

Fig. 1. Initial energy distribution of emitted electron by $\mathrm{Xe}^{+}$and $\mathrm{He}^{+}$

これは Hagstrum ${ }^{(3)}$ が実験によりW陰極に $\mathrm{He}^{+}$と $\mathrm{Xe}^{+}$ を入射したときの 2 次電子のエネルギー分布の测定値を参 考にしてまとめたものである。放出電子のエネルギーの最 大值 $\epsilon_{\max }$ は入射するイオンのポテンシャルエネルギー $\epsilon_{i}$ と陰極の仕事関数 $\phi$ を用いて

$$
\epsilon_{\max }=\epsilon_{i}-2 \phi
$$

\section{により与えた ${ }^{(3)}$ 。}

放出電子の 0 から $\epsilon_{\max }$ 間のエネルギー分布は実験值が見 当たらなかったため, $\mathrm{Ni}$ 陰極において測定された $0 \sim \epsilon_{\max }$ 間の分布が, W 陰極の場合の $0 \sim \epsilon_{\max }$ 間においてもその まま成り立つと仮定して与えた。言い獫えると,W 陰極の 場合の $0 \sim \epsilon_{\max }$ 間の分布は, $\mathrm{Ni}$ 㓌極に拄ける $0 \sim \epsilon_{\max }$ 間 で相似な形状を持つとして計算に用いた。ここで放出され る電子エネルギーの最大值は $\mathrm{He}^{+}$により放出される場合で あり $14.28 \mathrm{eV}$ である。図中 $\phi$ は $\mathrm{Ni}$ の仕事関数 $(5.15 \mathrm{eV})$ ， $\epsilon_{i}$ は $\mathrm{He}$ と Xe の電㒕電圧である。

$\mathrm{He}^{+}$と $\mathrm{Xe}^{+}$が放出する 2 次電子の割合は, 流体モデ ルのシミュレーション(1) の結果を参考にして, それらを 0.57:0.43 とした。また, $\mathrm{He}^{+}$と Xe $\mathrm{Xe}^{+}$以外の粒子による 2 次電子故出は相対的に少なかったという結果に従い, それ らは無視した。

このような分布で初期電子を放出した場合と, 前回の計 算で採用したように $0 \sim 0.1 \mathrm{eV}$ 間で等確率な初期エネルギー 分布で電子放出した場合の電子スオームの挙動について比 較検討した。

\section{3. 胡篮結果}

〈3.1〉SST 解析による比茭 (1) 月子エネルギー分 布の空向变化図 2 は 2 通りの初期エネルギー分布で電 子を放出した場合の電子エネルギー分布の空閒変化である。 同図 (a) は電子の初期エネルギーが 0 0.1eV で等確率な分 布で放出した場合 (以後, $[0 \sim 0.1 \mathrm{eV}]$ と記す) の, 同図 (b) は図 1 のような $\mathrm{He}^{+}$と $\mathrm{Xe}^{+}$が放出する電子のエネルギー 分布を初期エネルキー分布とした場合 (以後, $[0 \sim 14 \mathrm{eV}]$ と 記す) の結果である。
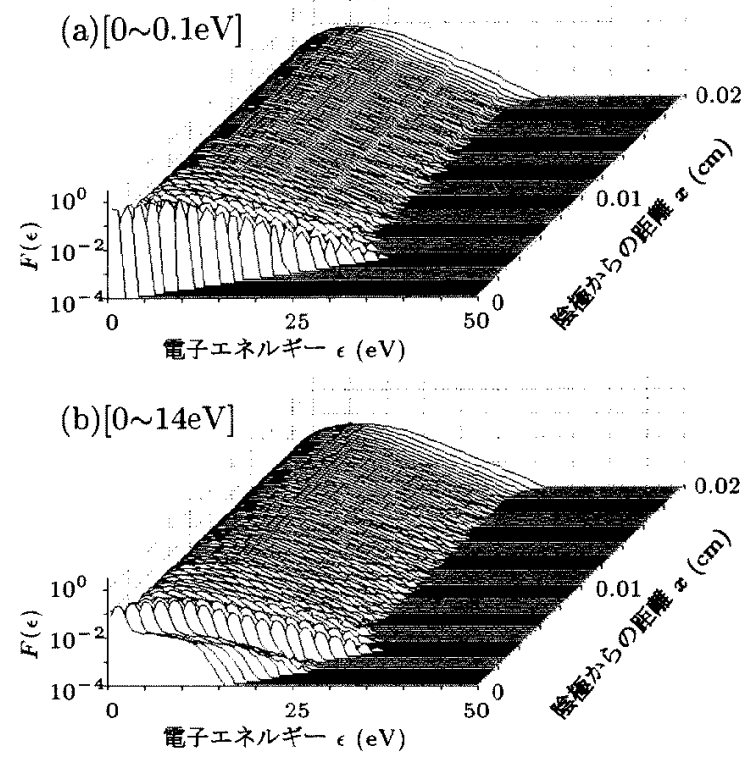

図 2 電子エネルギー分布の空間変化

Fig. 2. Spatial variations of electron energy distribution

陰極近傍を除けば，両者はほぼ一致している。陰極近傍 における分布の大きな違いに注目すると， $[0 \sim 0.1 \mathrm{eV}]$ で与 えた (a) では，電子エネルギー分布は陰極近傍でエネルギー 幅が狭く，高いピークをもつ形状となる。これは放出され た電子が $0 \sim 0.1 \mathrm{eV}$ の狭いエネルギー幅をもちながら加速 されることによる。次に，[0〜 14eV] で与えた (b) を見る と，陰極近傍における電子エネルギ一分布は図 1 の $\mathrm{He}^{+}$ と $\mathrm{Xe}^{+}$による分布を 0.57 と 0.43 の割合で重ね合わせた形 であり，ビークは $[0 \sim 0.1 \mathrm{eV}]$ よりも低く，高エネルギー側 に幅広く伸びた形状となる。このためエネルギー分布が一 定となるまでの距離は (a) では $0.008 \mathrm{~cm}$ (b) では $0.006 \mathrm{~cm}$ と、後者が若干短くなっている。

(2) 各程里子送係数図 3 にはXeの各種電子衝 突周波数，電子数分布，以下電子の $\mathrm{He}$ と Xe との弾性街 突数, $\mathrm{Xe} の$ 電離衝突数, $\mathrm{Xe} 1 s_{4}$ への励起数, $\mathrm{Xe} の$ 全励起 数そして，電子の平均エネルギーと電界方向移動速度，な どの空間変化を上から順に示してある。

左側の図は [0 0.1eV] の, 右側の図は $[0 \sim 14 \mathrm{eV}]$ の分布 で初期エネルギーを与えた場合の結果である。 

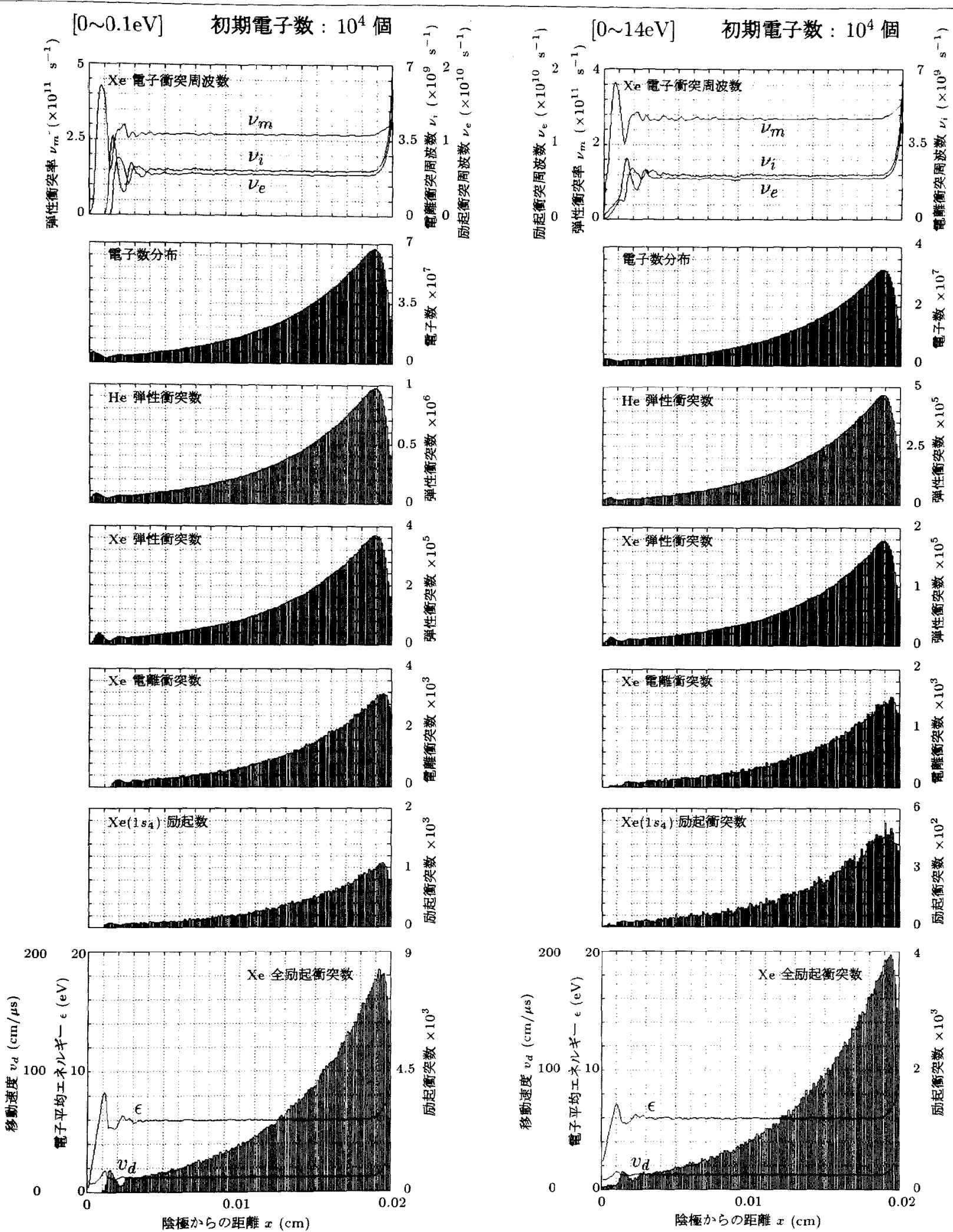

図 $3 \mathrm{Xe}$ の各種電子衝突周波数, 電子数分布, $\mathrm{He}, \mathrm{Xe}$ 弾性衝突, Xe 電離衝突数, $\mathrm{Xe}\left(1 s_{4}\right)$ 全励起衝突数，電子エネルギー，電界方向移動速度，Xe 全励起衝突数の空間変化

Fig.3. Spatial variations of electron collision rates, number of electron, number of elastic collision, number of ionizaition collision, number of excitation collision, electron mean energy, and electron drift velocity 
陰極近傍を除いたエネルギー平衡領域における電子輸送 係数を比㜞すると，両者はほとんど一致している。しかし， 各種衝突発生の空閒変化を比較すると, $[0 \sim 14 \mathrm{eV}]$ の結果 は $[0 \sim 0.1 \mathrm{eV}]$ に比べ，すべての種類の電子街突が減少して いる。

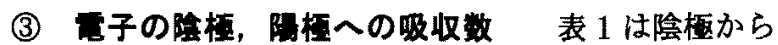
放出された電子の雨電極への吸収数と電離増倍率をまとめ たものである。特に陰極に吸収された電子数を比較すると， $\mathrm{b} の[0 \sim 14 \mathrm{eV}]$ の場合は aの $[0 \sim 0.1 \mathrm{eV}]$ の場合より 7 倍も 多くの電子が後方散乱により陰極に戻されているのが特徴 的である。

表 1 電子の電極への吸収数，電離増倍率

Table 1. Electron absorption number to the electrode and ionization multiplication factor

\begin{tabular}{|l|c|c|c|}
\hline & $\mathrm{a}:[0 \sim 0.1 \mathrm{eV}]$ & $\mathrm{b}:[0 \sim 14 \mathrm{eV}]$ & $(\mathrm{b} / \mathrm{a})$ \\
\hline 陰極吸収数 & 850 & 5980 & 7.035 \\
\hline 陽極吸収数 & 210006 & 100210 & 0.477 \\
\hline 電離増倍率 & 22.95 & 24.93 & 1.086 \\
\hline
\end{tabular}

\section{表 2 各種衝突数の積算值の比較}

Table 2. Comparison of the integrated value of various collision number

\begin{tabular}{|c|c|c|c|}
\hline 衝突回数 & $\mathrm{a}:[0 \sim 0.1 \mathrm{eV}]$ & $\mathrm{b}:[0 \sim 14 \mathrm{eV}]$ & $(b / a)$ \\
\hline 弹性銜突 $\mathrm{He}$ & 66115114 & 31441771 & 0.476 \\
\hline $\mathrm{Xe}$ & 24885332 & 11839819 & 0.476 \\
\hline 励起街英 $\mathrm{He}$ & 17927 & 8222 & 0.459 \\
\hline $\mathrm{Xe}$ & 521514 & 247843 & 0.475 \\
\hline $\mathrm{Xe} 1 s_{4}$ & 65956 & 31134 & 0.472 \\
\hline 電剩衙突 $\mathrm{He}$ & 1788 & 879 & 0.492 \\
\hline $\mathrm{Xe}$ & 199068 & 95311 & 0.479 \\
\hline 全行突回数 & 91806699 & 43664979 & 0.476 \\
\hline
\end{tabular}

(4) 回壦增倍率陰極に吸収されずに, 後方散乱効果 を逃れた電子は，ガス中に注入され電陮増倍をしながら，陽 極に吸収される。陽極吸収数とガス中に注入された電子数 即ち, 陰極放出数から陰極への吸収数を引いた值との比が 電極間の電雎増倍率となりこれも表 1 にまとめてある。 電離增倍率は $[0 \sim 0.1 \mathrm{eV}]$ より $[0 \sim 14 \mathrm{eV}]$ の方が 1.086 倍 すなわち約 1 割大きくなっている。このように電子の初期 エネルギー分布の違いは，エネルギーが大きいほどガス中 一の電子注入数が減少するが, 入った後の電子 1 個当りの 電灕增倍率は大きくなることを見出すことができた。この 增加分は図中の $\nu_{i}$ 曲線で説明できる。 $[0 \sim 14 \mathrm{eV}]$ の場合、 陰極前面から電離発生を観測しているが、 $[0 \sim 0.1 \mathrm{eV}]$ では $x=0.0015 \mathrm{~cm}$ 付近より電離が発生している。 $\nu_{i}$ 曲線の描 く面積の比が 1.086 を与えることになる。

(5) 各種㑑突回数の比较放電空間中の電子の各種街
突回数の積算値を表 2 に示した。bの $[0 \sim 14 \mathrm{eV}]$ における 衝突回数と, $\mathrm{a} の[0 \sim 0.1 \mathrm{eV}]$ における衙突回数の比 $(\mathrm{b} / \mathrm{a})$ も表示してある。全衛突回数の比は 0.476 であるが、これ らの内訳は衝突頻度の大きい弾性街突では $\mathrm{He}, \mathrm{Xe}$ とも 0.476 で全街突の場合と同じである, しかし、励起衙突で はHe,0.459, Xe,0.475, Xe 1s, 0.472 といずれも㒖かに小 さく、これに対して電雄衝突数では $\mathrm{He}, \mathrm{Xe}$ とも 0.492 と 0.479 と大きくなった。電子の初期エネルギーを大きくす ると以上のように電子衛突の内訳が変化することがかかる。 これらは、弾性衝突回数に比べて圧倒的にサンプル数が少 なかった上での議論であるが、その発生確率が試行回数、 この場合は初期電子数であるが、この值に依存することは 本質的にはあり得ないものと著者らは考える。発生確率の 小さい電離や励起について詳細な情報を収集しようとすれ ば、更に多くの電子について計算しなければならなくなる のは当然のことである。

初期エネルギーを 2 つの分布で与えた結果より全街突回 数の比は，弾性衝突と同じ 0.48 であり，衛突の種類では電 䧻衝突の比が $[0 \sim 14 \mathrm{eV}]$ の場合に唯一增加している。この ことは電子を大きいエネルギーで注入すれば陰極前面のエ ネルギー韭平衡領域内から電子衛突電離が発生し、電離衝 突数が堌加することを示している。

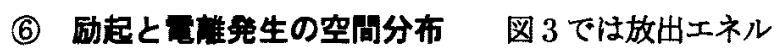
ギー分布の違いは陰極近傍における励起や電離の発生分布 にも変化を与えている様子が確認できる。即ち， $[0 \sim 14 \mathrm{eV}]$ では陰極近くから励起や電離衙突が発生していることを確 認できた。

\section{〈3-2〉 PT 解析による比較}

(1) 空子エネルギーの時間交化 図 4 に電子エネルギー 分布の時間変化を示した。同図 (a), (b) 注電子の初期エネ ルギーが $[0 \sim 0.1 \mathrm{eV}]$, 同図 (c), (d) は $[0 \sim 14 \mathrm{eV}]$ のそれぞ れの結果である。電子の追跡時間 T は (a) と (c) が 20ps, (b) と (d) が 200ps である。エネルギー分布の時間軸はすべ ての図で手前を時刻 0 としている。 $[0 \sim 0.1 \mathrm{eV}],[0 \sim 14 \mathrm{eV}]$ の再者とも, 陰極を出発した直後の分布は陰極放出時の初 期エネルギー分布の形で保たれているが, 衝突によりエネ ルギーが緩和して, エネルギー平衡状敫になるまでの時間 は $[0 \sim 0.1 \mathrm{eV}]$ は $50 \mathrm{ps},[0 \sim 14 \mathrm{eV}]$ では $30 \mathrm{ps}$ ，と後者の方が 短かくなった。

表 3 は電子放出後の時刻 $t=20,200 p s$ における電子ス オームの重心位置 $x_{g}$ を示してある。この表より, $[0 \sim 0.1 \mathrm{eV}]$ の重心位置の方が $[0 \sim 14 \mathrm{eV}]$ のそれよりも陽整奇りに移動 していることがわかる。これは後でも述へるが, $[0 \sim 0.1 \mathrm{eV}]$ では, 電子は Ramsauer 極小のエネルギ一領域を通過する ため, 電子の飛行距離が長くなり, 電子の前方向速度が大 きくなるためである。また, 電子が陰極から放出された直 後の $20 \mathrm{ps}$ では両者の差は大きいが, 時間の経過とともに， 特に Xe の Ramsauer 極小を通り拔けた電子は十分衝突す るようになり，その差が次第に小さくなっていることも明 らかとなった。 
表 3 電子スオームの重心の位盢

Table 3. Center of position of the electron swarm

\begin{tabular}{|c|c|c|c|}
\hline \multirow{2}{*}{ 時刻 $\mathrm{T}(\mathrm{ps})$} & \multicolumn{2}{|c|}{ 重心位置 $x_{g}(\mathrm{~cm})$} & \multirow{2}{*}{$(\mathrm{b} / \mathrm{a})$} \\
\cline { 2 - 3 } & $\mathrm{a}:[0 \sim 0.1 \mathrm{eV}]$ & $\mathrm{b}:[0 \sim 14 \mathrm{eV}]$ & \\
\hline 20 & 0.000423 & 0.000373 & 0.882 \\
\hline 200 & 0.003372 & 0.003358 & 0.996 \\
\hline
\end{tabular}

(2) 各程目子等保数 図 5 に電子の开均エネルギー $\boldsymbol{\epsilon}$, 速度空間の電界方向移動速度 $w_{v}$, Xe の電離街突数，同 しく全励起衙突数, 同 $1 s_{4}$ 二の励起衛突数, $\mathrm{He}$ と Xe との それぞれの弾性衙突数，電子数 $\mathrm{N}$ 等の時閒変化を示した。 図中に付けた記号 (a)〜 (d) は前項(1)の埸合と同棣であるが, 2 枚 1 組として表してある。

電子を $20 \mathrm{ps}$ まで追跡して計算した結果 (a), (c) に注目 すると，速度空間の電界方向移動速度 $w_{v}$ に大きな逗いが見 られる。(a) では $4 \mathrm{ps}$ 付近に $36 \mathrm{~cm} / \mu \mathrm{s}$ のピークをもつ変化 であるのに対して，(c) では $\mathrm{t}=0$ 直後から $50 \mathrm{~cm} / \mu \mathrm{s}$ 付近 にピーク值を持ち、その後急激に減少している。(a) の $w_{v}$ がピークを描くのは電子が Xe との弾性衝突の Ramsauer 極小の $0.64 \mathrm{eV}$ を通過するため,ここでの衙突数は隇少し， 従って飛行距離が長くなり，前方向速度が一気に增すこと による。これは， $w_{v}$ がピークをとる前の $3 \mathrm{ps}$ 付近で電子 と Xe との弾性衝突数が極端に減少しながら $\epsilon=0.64 \mathrm{eV}$ を 通過していることからもよく理解できることである。これ に対して (c) の場合は， $\epsilon$ は最初から $4 \mathrm{eV}$ 付近から増加し， Xe の Ramsauer 極小をはるかに越えているため，(a)の 場合のような $w_{v}$ のピークは䘽測されない。

Xe の全励起衙突数の变化に注目すると，(a) の場合は 12ps 付近から立ち上がるが，(c) の場合は電子放出直後か ら励起衝突が発生し，10ps 辺りで (a) よりも大きい值で 飽和している。Xe1s $s_{4}$ の励起も似た変化をしている。さら に (a) では 20ps 付近から立ち上がるようにしが䚑されな かった Xeの電離も盛んに発生している。電子の初速度が 大きかった効果がこのような形で現れている。

(b)，(d) 怯電子の 200ps まで追跡して計算した結果であ る。平均エネルギー $\epsilon$ と, 速度空間の電界方向移動速度 $w_{v}$

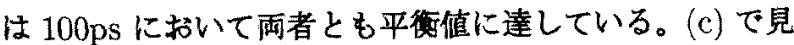
られた Xe の全励起街突数が，10ps 付近より頭打ちする変 化は，(d)でも見られる。しかし，(b)では25ps，(d) では これより早い $10 \mathrm{ps}$ 付近から主にXe との電䭛衙㔖が発生し 電子数の増倍が钼測されている。これに伴ってXe の全励 起と $1 s_{4}$ へのそれぞれの励起衙突数は再び増加している。 電子数 $N$ の曲線は (d) の方が急增していることもわかる。

\section{4. まとめ}

陰極から放出する初期電子のエネルギー分布を変えた場 合, PDP セル内の電子スオームがとのような影謷を受け るか MCSにより検討した。
$[0 \sim 0.1 \mathrm{eV}]$ 初期電子数 : $10^{6}$ 個
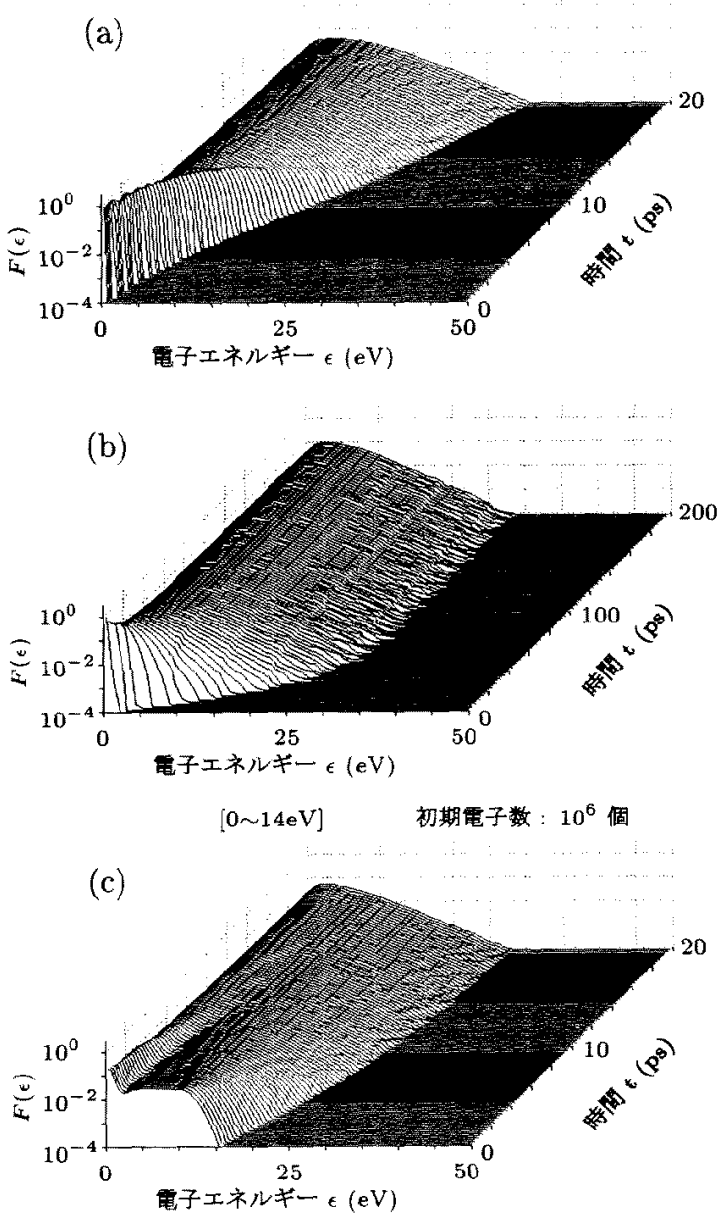

(d)

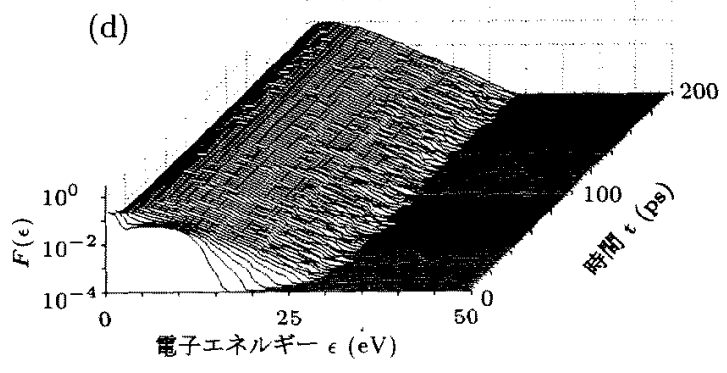

図 4 電子エネルギー分布の時間変化

Fig.4. Temporal variations of electron energy distribution

(1)電子エネルキーの空間変化は陰極近傍で異なり，エネ ルギー平衡距離は $[0 \sim 14 \mathrm{eV}]$ の場合の方が短かくなる 結果が得られた。

(2)各種衛突発生数は, $[0 \sim 14 \mathrm{eV}]$ の場合は $[0 \sim 0.1 \mathrm{eV}]$ の 場合に比べ，すへての衝突においてその数が減少した。 これは，前者の方が後方散乱する電子が 7 倍も多く，ガ ス中に注入される電子数が減少したことが原因である。

(3)しかし後方散乱を逃れた電子が一旦ガス中に入ると， 高いエネルギーをもつ $[0 \sim 14 \mathrm{eV}]$ の場合は $[0 \sim 0.1 \mathrm{eV}]$ 

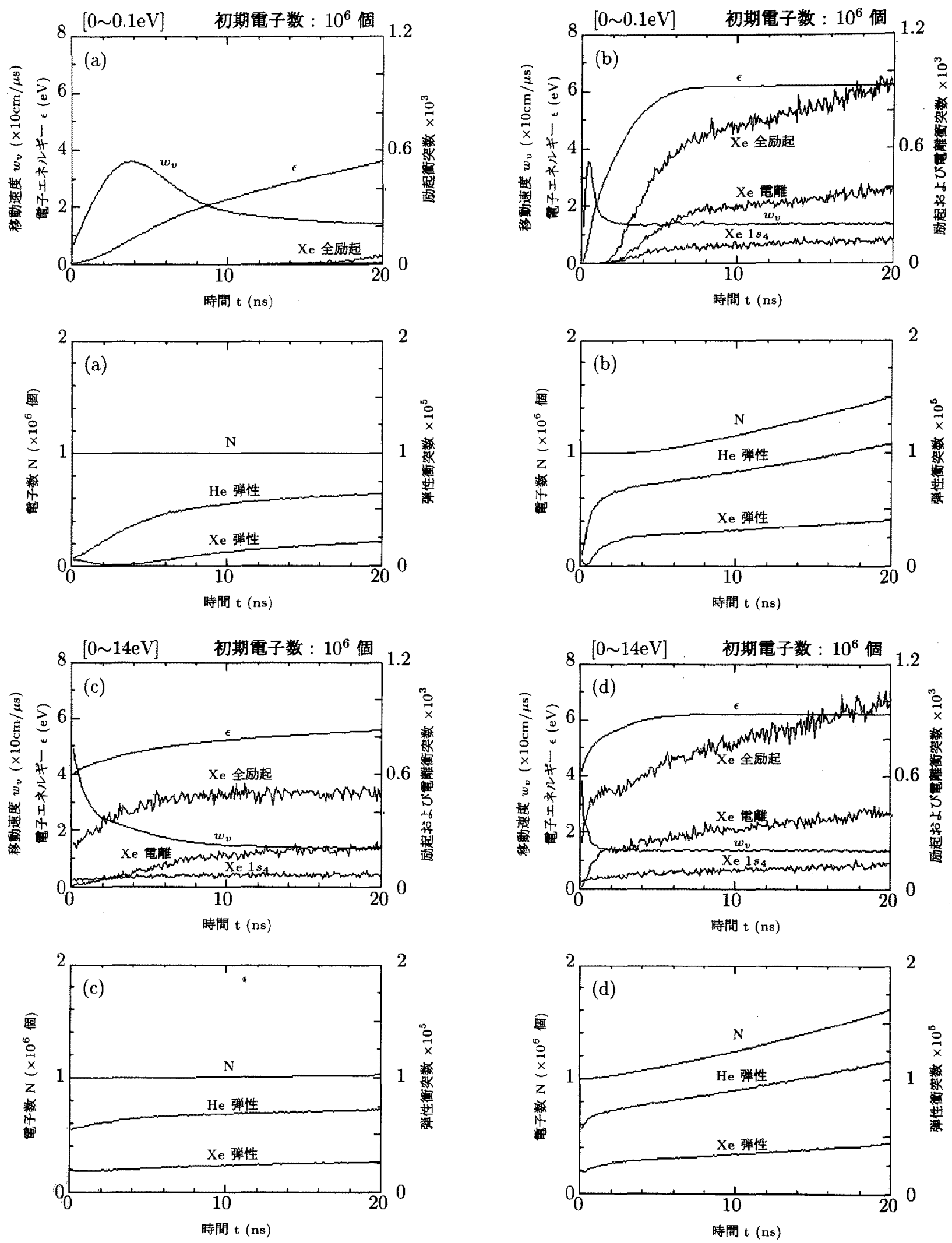

図 5 電子の平均エネルギー $\epsilon$, 電界方向移動速度 $w_{v}, \mathrm{Xe}$ 全励起衝突数,

$\mathrm{Xe}\left(1_{s 4}\right)$ 励起衝突数, Xe 電䕙衝突数, $\mathrm{He}, \mathrm{Xe}$ 弹性衝突数, 電子数密度 $N$ の変化

Fig.5. Temporal variation of electron mean energy $\epsilon$, electron drift velocity $w_{r}$, number of excitation collision, number of ionization collision, number of elastic collision and number of electron $N$ 
と比較して陰極近くの非平衡領域での電離衝突の増加 により、全皃突数の中での電離発生の割合を増加する ことに寄与する。今回の条件の下では約 $10 \%$ 電離増 倍率が大きくなることが分かった。

(4)電子エネルギー分布が平衡状態に達する時間は $[0 \sim 14 \mathrm{eV}]$ の埸合の方が短かかった。(1) の結果と共に, 大きいエ ネルギー損失を伴う衝突が多く発生する程速やかにエ ネルギー緩和することによると考えられる。

(5)電子スオームの重心位置 $x_{g}$ は, 放出直後では $[0 \sim 0.1 \mathrm{eV}]$ の場合の方が Ramsauer 極小に相当するエネルギー域 を通過するため陽極方向へより速く移動している。時 間の経過とともにその差は炊第に小さくなった。

(6)速度空間の電界方向移動速度 $w_{v}$ は, $[0 \sim 0.1 \mathrm{eV}]$ の場 合では極大値もつ变化であるのに対して, $[0 \sim 14 \mathrm{eV}]$ の 場合では $\mathrm{t}=0$ より単調に隇少した。

衝突断面積データを提供して頂きました気体エレクトロ ニクス研究所 林 䢐博士に感謝の意を表します。

(平成 12 年 8 月 8 日受付, 同 13 年 2 月 5 日再受付)

\section{文藏}

(1) Y.Murakami, J.Koike, H.Murakami and K.Tachibana : Proceedings of the 4th International Display Workshop, 567 570 (1997)

（2）福山, 伊藤, 村上, 松崎：電学論, 119-A, 286 291 (1999)

(3) H.D.Hagstrum : Phys. Rev., Vol.104, $317 \sim 318$ (1956)

（4）福山, 伊藤 : 電学論 118-A, 543 548 (1998)

（5）福山, 伊藤, 山本, 生田：電学論 116-A, 529 535 (1996)

（6）プラズマ材料科学ハンドブック, オーム社 (1992)

福山莲也（正員） 1967 年 12 月 9 日生。99 年 3 月, 千葉工

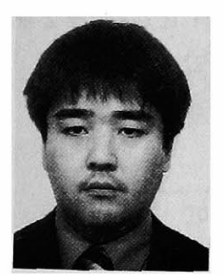
業大学大学院工学研究科電気電子工学専攻博士課 程修了。現在千葉工業大学助手。博士 (工学)。放 電現象, 固体絶縁材料の研究に従事。

伊蔍明 塔

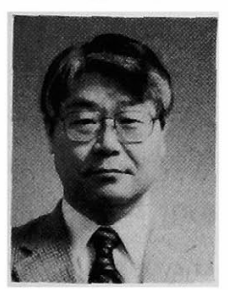
業大学電気工学科卒業。6 8 年 4 月 70 年 3 月理 化学研究所勤務。72 年 3 月徳島大学大学院工学 研究科修士課程修了。同年 4 月千苯工業大学助手, 現在，同教授。放電基礎過程の研究に従事。工学 博士。日本物理学会, 応用物理学会, 静電気学会 会員。 